\title{
Integrated Risk Management Model Implementation's Contextual Dependence on Company Size
}

\begin{abstract}
NURI MOHAMED SAAD ALHERIANI, University of Belgrade, Faculty of Mechanical Engineering, Belgrade VESNA K. SPASOJEVIĆ BRKIĆ, University of Belgrade, Faculty of Mechanical Engineering, Belgrade MARTINA B. PERIŠIĆ, University of Belgrade, Faculty of Mechanical Engineering, Belgrade ABDULGHDER MOHAHMED ALSHARIF, University of Belgrade,

Faculty of Mechanical Engineering, Belgrade

Original scientific paper UDC: 005.334

006.85

005.336.3:334.012.61

DOI: 10.5937/tehnika2103361A

Novel integrated risk management model for standardized management systems, such as ISO 9001:2015 for quality management systems, ISO 14001:2015 for environmental management systems, ISO/IEC 27001:2013 for information security management systems, ISO 45001:2018 for occupational health and safety management systems, and ISO 22000:2018 for food safety management systems, has been proposed in order to enable that organizations can manage their processes and associated risks versus requirements of each internal and external stakeholder, due to the fact that those models rarely exist in literature. Proposed model consists of three levels - correspondence, coordination and integration and put in place a clear and structured approach to controlling organizational risks. Using sample of 30 Serbian companies the proposed model has been checked empirically to contextual independence of proposed model using Mann-Whitney $U^{*}$ test and it has been proved that model is context free and applicable to companies different in size since there were no differences between micro \& small vs. medium \& large companies. Limitation of this research for sure is the sample size, so its extension is recommended. Further recommendation for future research is also a more detailed analysis on collected data done by using more sophisticated statistical analysis tools, such as regression analysis, structural equations modeling and similar to see interrelations between variables in the proposed model.
\end{abstract}

Key words: Risk Management; Standard; Context; Company size

\section{INTRODUCTION}

Companies nowadays operate in turbulent environment of very prominent producer competition and developed distribution channels, where there is a significantly higher volume of products and services then the environment is capable of absorbing. In order for the organization to survive in such conditions, it is not sufficient to be average, and therefore it strives towards sustainable development in order to achieve business excellence characteristics [1].

Achieving excellence is not as the contingency/

Author's address: Nuri Mohamed Saad Alheriani, University of Belgrade, Faculty of Mechanical Engineering, Belgrade, Kraljice Marije 16

e-mail: nurisaad58@gmail.com

Paper recived: 04.02.2021.

Paper accepted: 14.04.2021. contextual approach to management is based on the idea that there is no universally appropriate design applicable to all organizations in all circumstances and it is evident that contextual/contingency factors influence management standards adoption level [2, 3].

Sustainable development has three main dimensions represented in the economy, environmental and social dimension. Consequently, most of the organizations in the world currently seek to create a balance between those elements in the highly competitive market, not only to overcome economic and environmental crises however to gain many other benefits such as improving organizational performance, increasing productive capacity flexibility, high operational efficiency, improved health and safety aspects and market expansion.

On the other hand, there is a significant increase in the uncertainty that brings significant risks with it, so 
that business entities are critical to managing its internal and external risks. Also, the specifics of the context of each of the companies require specific solutions [4] as depicted by contextual approach.

Companies all over the world today are increasingly implementing different standards for management systems based on the request of stakeholders so that quality, environment and occupational health and safety are among the most researched and implemented standards for their role in maintaining human health, environment, and quality which has become an instrument to compete with others and achieve desired goals which contribute to sustainable development.

Also, implementing management standards in a way that they are independent from each other often is causing multiple burdens on the organization's business processes in manner that to meet the certification requirements for each standard, organizations need numerous documents, written procedures, forms of auditing and control in addition to other paperwork, and therefore the implementation of these standards in the organization independently of each other leads to multiple weaknesses such as duplication of tasks and processes in all management systems, an increase in the cost of certification issuance and maintenance of standards, in incremental consumption in the organization resources etc. Accordingly, the integration of these standards under a single roof has become the focus of the attention of successful companies today [5].

On the other hand, there are various obstacles in possible implementation of the integrated management system (IMS) that companies should take into accounts. Attention has to paid to issues such as: insufficient resources, lack of motivation for employees, the participation of top management and their commitment, insufficient training, the inadequacy of guidance for integration, attitudes that lead to negative results and lack of skilled auditors and consultants etc. $[6,7]$.

\section{LITERATURE REVIEW}

IMS is used in many organizations today with the aim of leaving traditional management routines and replacing them with advanced management schemes [8].

Numerous studies and papers could be reviewed to identify the most important weaknesses in the development of risk management integrated models in standardized management systems and to build the appropriate model. So in 2012, a research study [9] was conducted in Iran concerning event analysis and verification of the impact of integrated management systems on health and safety performance indicators in power plants. The study was conducted by analyzing the data and knowing the percentage of victims' accidents before and after applying the international monitoring system and forecasting the future to show these results to us the extent to which the use of integrated management systems greatly contributed to reducing accident indicators and thus improving safety in this industry during the test period and therefore recommended that this be applied an approach in other industries [9]. Integration based on risk analysis and value engineering is proposed by authors in [10] as very efficient and effective method. Authors in [11] analyzed two ways of integration based on risk analysis: 1. the introduction of individual systems followed by the integration of the originally separate systems, and 2. the development and implementation of an integrated management system, integrated from the very beginning. Both ways were tested in the form of case studies and demonstrated the functioning of the theoretical model for implementation of risk analysis based management systems. According to the previous studies and literature review of the integrated management system, there are main aspects which must be taken into consideration when studying the process of integration and which are including the following categories: definitions and philosophies of IMS; factors affecting IMS; strategies for implementing IMS; levels of integration; methodologies and models of IMS; and Auditing system's integration [4, $12,13]$. In accordance with $[14,15]$, the PDCA cycle is a tool that can be used to successfully manage processes and systems in IMS. Additionally, one of the most important clauses in management standards urges organizations to include risk management to be an integral part not distinct of other organizational processes, and thus risk management should be integrated into the organization and an important component in policy determining, strategic planning, and influence and consequently change management processes [16].

However, till now has not been found a framework to define a common and unified standard model for integrated management systems that can be used to mitigate risks and which is applicable in all contingency factors settings [17]. Extremely important contingency factor is company size, as proposed in [18].

\section{METODOLOGY}

The empirical survey intended to survey the influence of company size on risk management practice proposed as in model in [19], based on clauses from covered management standards - ISO 9001, ISO 14001, ISO 45001, ISO 27001, and ISO 22000, as in 


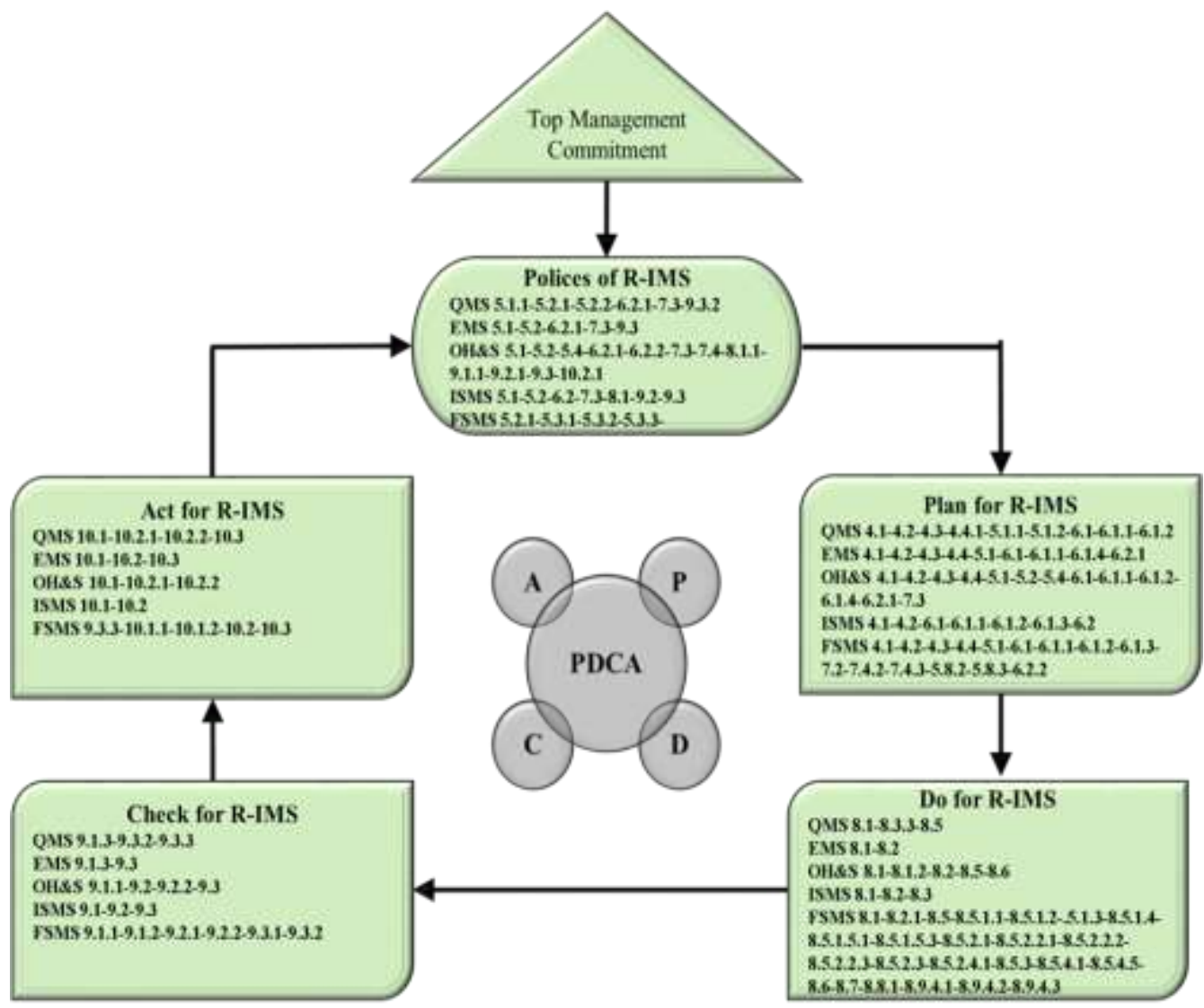

Figure 1 - Clauses and sub clauses of IMS based on risk management and PDCA [19]

Figure 1, has been conducted surveying Serbian companies in order to analyze the level and manner of integration of risk management practice.

The survey contained a cover letter and a questionnaire. The cover letter provided general information about the questionnaire and the purpose of studying the mentioned standards while alerting companies to the confidentiality of their information and anonymity, in addition to the benefits of studying and participating in scientific research and contact information. The questionnaire was split into four divisions, the first part included information about the surveyed companies, and the second included information on the standards of management systems involved, while the third included the integration of management systems such as methods used in the integration and levels of integration in addition to the benefits and difficulties in implementation, whereas the fourth part included integration based on risk. The fourth part of the questionnaire is subjected in this paper.

The survey link was sent via email to about 200 Serbian companies certified to mentioned management standards. After 3 months, and two reminders, 30 companies belong to ten different industrial sectors have answered. The largest part of companies which have participated in this survey operated in manufacturing sector with $20 \%$, followed by energy and construction sectors by $17 \%$. Average value of number of employees in companies which have participated in survey is 276. Also, companies different in size have participated in survey, as in Figure 2. There were 33\% of small and large companies, and $17 \%$ of micro and medium sized companies in the sample. The MannWhitney U test has been used to compare differences between two independent groups, since the dependent variable is either ordinal or continuous, but not normally distributed and results will show if there are significant differences.

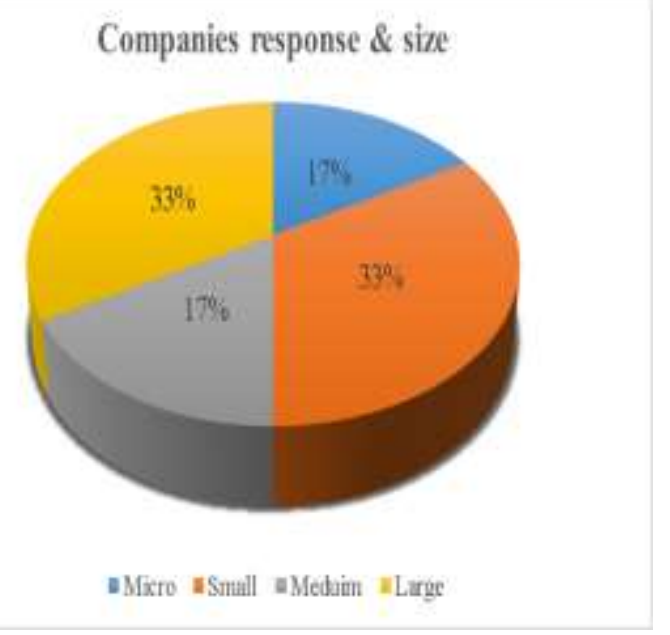

Figure 2 - Survey respondents by company size 


\section{RESULTS}

The Mann-Whitney $U$ test is used to compare differences between two independent groups - micro \&small vs. medium \& large company sized companies, as recommended in $[20,21]$, and results show that there are no significant differences. Accordingly, as in
Table 1, it is evident that the proposed model is not dependent on context regarding company size, since there were not evidenced significant differences on given answers, which means that the proposed model, based on clauses given in Figure 1, application, independently of company size could be recommended.

Table 1. Comparisons between micro \&small vs. medium \& large company sized companies attitudes on risk model using Mann-Whitney $U^{*}$ test

\begin{tabular}{|c|c|c|c|}
\hline $\begin{array}{l}\text { Micro \& Small vs. Medium \& Large company size In our organization top } \\
\text { management ... }\end{array}$ & Z statistic & $\mathrm{p}$-value & significance \\
\hline $\begin{array}{l}\text {... should establish risk based policies/objectives to set and follow the realization of } \\
\text { the goals of the standards. }\end{array}$ & 0.235702 & 0.813664 & n.s. \\
\hline $\begin{array}{l}\text {...should establish risk based policies/objectives that are appropriate to the purpose } \\
\text { and context of the organization including the nature, scale, and impacts of its } \\
\text { activities, products, and services. }\end{array}$ & 0.235702 & 0.813664 & n.s. \\
\hline $\begin{array}{l}\text {... should establish risk based policies/objectives that include a commitment to } \\
\text { continual improvement of aspects such as quality, environment, health, and } \\
\text { safety.....etc. }\end{array}$ & 0.707107 & 0.497500 & n.s. \\
\hline $\begin{array}{l}\text {... should establish risk based policies/objectives that include a commitment to legal } \\
\text { and legislation requirements. }\end{array}$ & -0.942809 & 0.345779 & n.s. \\
\hline $\begin{array}{l}\text {... should establish policies/objectives that are based on risk evaluation and } \\
\text { opportunities. }\end{array}$ & -0.666667 & 0.504985 & n.s. \\
\hline $\begin{array}{l}\text {... should establish risk based policies/objectives that include a commitment to } \\
\text { participation, i.e. the involvement of workers and employees. }\end{array}$ & 0.235702 & 0.813664 & n.s. \\
\hline $\begin{array}{l}\text {... should establish risk based policies/objectives that reward employees for the } \\
\text { achieved risk management mitigation. }\end{array}$ & -0.449467 & 0.653095 & n.s. \\
\hline $\begin{array}{l}\text {... should plan to identify all the processes and procedures necessary to address risk } \\
\text { in terms of objectives, sequence, input and output, key performance indicators, and its } \\
\text { criteria. }\end{array}$ & -0.463739 & 0.642835 & n.s. \\
\hline $\begin{array}{l}\text {... should plan to identify all the adequate resources to address the different types of } \\
\text { risks }\end{array}$ & -0.463739 & 0.642835 & n.s. \\
\hline $\begin{array}{l}\text {.... should plan to determine the risk management processes in terms of risk } \\
\text { identification, risk analysis, risk evaluation, and risk treatment. }\end{array}$ & -0.449467 & 0.653095 & n.s. \\
\hline $\begin{array}{l}\text {... should clearly define organizational structure, roles, powers and responsibilities } \\
\text { for risk management. }\end{array}$ & -0.666667 & 0.504985 & n.s. \\
\hline $\begin{array}{l}\text {...should provide regularly training related to quality, environment, health, and } \\
\text { safety...etc. to all workers and levels in the organization. }\end{array}$ & -0.449467 & 0.653095 & n.s. \\
\hline $\begin{array}{l}\text {...should communicate and consult all stakeholders at all stages of the risk } \\
\text { management process. }\end{array}$ & -0.228218 & 0.819227 & n.s. \\
\hline $\begin{array}{l}\text {...should supervise and participate in the identification of risks with their likelihoods } \\
\text { and consequences to calculate the magnitude of risks. }\end{array}$ & 1.290994 & 0.196706 & n.s. \\
\hline $\begin{array}{l}\text {...should document the results of the monitoring and review of the risk management } \\
\text { process. }\end{array}$ & -0.235702 & 0.813664 & n.s. \\
\hline $\begin{array}{l}\text {...should compare the magnitude of risk to the predefined criteria in a systematic } \\
\text { periodic time. }\end{array}$ & 1.290994 & 0.196706 & n.s. \\
\hline $\begin{array}{l}\text {...should identify and assess options of risks in order to determine the priorities of } \\
\text { risks that need to be treated. }\end{array}$ & -0.707107 & 0.479500 & n.s. \\
\hline ...should implement corrective and preventive actions. & -0.463739 & 0.642835 & n.s. \\
\hline ...should implement internal and external audit program. & 0.442807 & 0.657905 & n.s. \\
\hline ...should implement a management review in a systematic and periodic time. & 0.664211 & 0.506555 & n.s. \\
\hline ...should implement risk treatment for all risks & -1.123666 & 0.261105 & sign. \\
\hline ...should select the options for risk treatment. & -0.235702 & 0.813664 & n.s. \\
\hline ...should prepare and implement risk treatment plans. & -0.942809 & 0.345779 & n.s. \\
\hline
\end{tabular}




\section{CONCLUSION}

Many researchers, in recent years, have linked the frequent failures of certification programs to contingent factors [2,3]. So, herein, has been checked if risk modeling practice, as in model proposed and explained in detail in [19], is context dependant regarding the company size as contextual factor.

It has been shown, by applying the Mann-Whitney $\mathrm{U}$ test, which is used to compare differences on risk modeling in IMS framework between micro and small vs. medium and large sized companies, that there are no significant differences proved, which means that the proposed model is applicable whatever the company size is.

Limitation of this research for sure is the sample size, so its extension is recommended. Further recommendation for future research is also a more detailed analysis on collected data done by using more sophisticated statistical analysis tools, such as regression analysis, structural equations modeling and similar to see interrelations between variables in the proposed model.

\section{ACKNOWLEDGEMENT}

The survey is supported by grants from the Ministry of Education, Science and Technological Development, grants from project E!13300 and contract 451-03-68/2020-14/200105 (subproject TR 35017).

\section{REFERENCES}

[1] Algheriani NMS. Business Standardization in the World - State of the Art, International Journal of Advanced Quality, vol. 44, No. 1, pp. 47-57, 2017.

[2] Spasojević Brkić V. K, Klarin M. M, Brkić A. D, Lučanin V. J, Milanović D. D, Simultaneous consideration of contingency factors and quality management: An empirical study of Serbian companies. African Journal of Business Management, Vol.5, No. 3, pp. 866-883, 2011.

[3] Lo C. K, Wiengarten F, Humphreys P, Yeung AC, Cheng T. C. E. The impact of contextual factors on the efficacy of ISO 9000 adoption. Journal of Operations Management, Vol. 31, No.5, pp. 229-235, 2013.

[4] Muthusamy G, Palanisamy C, Mohanraj M. A comprehensive model and holistic approach for implementing an integrated management systems. Journal of Computational and Theoretical Nanoscience, Vol. 15, No.1, pp. 392-401, 2018.

[5] Domingues J. P. T, Sampaio P, Arezes P. M, Analysis of integrated management systems from various perspectives, Total Quality Management \& Business
Excellence, Vol. 26, No. 11-12, pp. 1311-1334, 2015.

[6] Benyettou S, Abdellatif M. Empirical study on the integrated management system in Algerian companies, Journal of Industrial Engineering and Management (JIEM), Vol. 11, No. 1, pp. 135-160, 2018.

[7] Jørgensen T. H, Remmen A, Mellado M. D. Integrated management systems-three different levels of integration, Journal of cleaner production, Vol. 14, No. 8, pp. 713-722, 2006.

[8] Domingues J. P. T, Sampaio P, Arezes P. M. Analysis of integrated management systems from various perspectives, Total Quality Management \& Business Excellence, Vol. 26, No. 11-12, pp. 1311-1334, 2015.

[9] Laal F, Pouyakian M, Madvari R. F, Khoshakhlagh A. H, and Halvani G. H, Investigating the Impact of Establishing Integrated Management Systems on Accidents and Safety Performance Indices: A Case Study, Safety and Health at Work, Vol. 10, No. 1, pp. 54-60, 2019.

[10]Anđelić O. R, Rakićević Z. M, \& Nikolić V. N. Integral approach to risk analysis and value engineering, Tehnika, Vol. 75, No. 1, pp. 94-100, 2020.

[11]Labodová A, Implementing integrated management systems using a risk analysis based approach, Journal of cleaner production, Vol. 12, No. 6, pp. 571-580, 2004.

[12]Bernardo $\mathrm{M}$, Integration of management systems as an innovation: A proposal for a new model, Journal of Clean Production, Vol. 82, pp. 132-142, 2014.

[13]Bernardo M. Gianni M, Gotzamani K, Simon A. Is there a common pattern to integrate multiple management systems? A comparative analysis between organizations in Greece and Spain, Journal of Clean Production, Vol. 151, pp. 121-133, 2017.

[14]Nunhes T. V, Motta Barbosa LCF, Oliveira OJ. Identification and analysis of the elements and functions integrable in integrated management systems, Journal of Clean Production, Vol. 142, pp. 3225-3235, 2017.

[15]Gupta P. Beyond PDCA-A New Process Management. Quality progress, Vol. 39, No. 7, pp. 45-53, 2006.

[16]Berger T, Gleissner W, Integrated management systems: linking risk management and management control systems. International Journal of Risk Assessment and Management, Vol. 21, No. 3, pp. 215-23, 2018.

[17]Savino M. M, Batbaatar E, Investigating the resources for Integrated Management Systems within 
resource-based and contingency perspective in manufacturing firms. Journal of cleaner production, Vol. 104, pp. 392-402, 2015.

[18]Spasojević Brkić V, Klarin M, Radojičić M, Brkić A, Tomić B. Interdependence of contingency organizational factors in national industrial enterprises. Tehnika, Vol. 66, No. 1, 133-142, 2011.

[19]Algheriani NMS, Majstorovic V. D, Kirin S, Spasojevic Brkic V. Risk model for integrated management system. Tehnicki Vjesnik, Vol. 26, No. 6, pp. 1833 1840, 2019.

[20] Mann-Whitney U Test, in MacFarland TW, Yates J. M. Introduction to nonparametric statistics for the biological sciences using $R$ Ch.4, Springer, Cham, 2016.

[21]Ruxton G. D, The unequal variance t-test is an underused alternative to Student's t-test and the MannWhitney U test. Behavioral Ecology, Vol. 17, No. 4, pp. 688-690, 2006.

\title{
REZIME
}

\section{KONTEKSTUALNA ZAVISNOST PRIMENE INTEGRISANOG MODELA MENDŽMENTA RIZIKOM OD VELIČINE PREDUZEĆA}

\begin{abstract}
S obzirom na primetan nedostatak prethodnih istraživanja, a da bi se omogućilo organizacijama da upravljaju svojim procesima i povezanim rizicima u odnosu na zaheve svake interne i eksterne zainteresovane strane, predložen je novi integrisani model menadžmenta rizikom, koji obuhvata standarde ISO 9001:2015 za sisteme menadžmenta kvalitetom, ISO 14001:2015 za sisteme upravljanja životnom sredinom, ISO/IEC 27001:2013 za sisteme menadžmenta bezbednošću informacija, ISO 45001:2018 za sisteme menadžmenta bezbednošću i zdravljem na radu i ISO 22000:2018 za sisteme menadžmenta bezbednošću hrane. Novopredloženi model se sastoji iz tri nivoa - korespondencije, koordinacije i integracije i uspostavlja jasan i struktuiran pristup upravljanju organizacionim rizicima. Na uzorku od 30 srpskih kompanija predloženi model je empirijski proveren kako bi se ispitala kontekstualna nezavisnost predloženog modela po pitanju veličine preduzeća primenom Mann-Whitney $U^{*}$ testa $i$ dokazano je da je model primenljiv na kompanije različitih veličina, jer nije bilo razlika između mikro $i$ malih u odnosu na srednja i velika preduzeća. Ograničenje ovog istraživanja je veličina uzorka, pa se preopručuje njegovo proširenje. Preporuka za dalja istraživanja je i detaljija analiza prikupljenih podatka uz primenu sofisticiranijih alata za statističku analizu, kao npr. regresione analize, modeliranja strukturnim jednačinama i slično, a da bi se istražile međusobne veze svih promenljivih u novopredloženom modelu.
\end{abstract}

Ključne reči: menadžment rizikom, standard, kontekst, veličina preduzeća. 